Jurnal Akuntansi \& Manajemen

Vol.11, No.1, 2016

\title{
Penyajian Laporan Keuangan Sekolah Berbasis Database pada Sekolah Dhuafa
}

\author{
Eliyanora ${ }^{1}$, Firman Surya ${ }^{2}$, Hidayatul Ihsan ${ }^{3}$ \\ 1 Jurusan Akuntansi, Politeknik Negeri Padang \\ Email:norabuan93@gmail.com \\ 2 Jurusan Akuntansi, Politeknik Negeri Padang \\ Email: firm4n2003@gmail.com \\ 3Jurusan Akuntansi, Politeknik Negeri Padang \\ Email: ihsanm@gmail.com
}

\begin{abstract}
Abstrak
SMK dhuafa Nusantara dan MTsS Dhuafa Nusantara merupakan dua sekolah yang menyelenggarakan pendidikan/sekolah gratis bagi kaum dhuafa yang berlokasi di kota Padang. Kedua sekolah ini telah memberikan kontribusi untuk ikut mencerdaskan kehidupan bangsa. Karena kedua sekolah ini tidak memungut biaya apapun kepada anak didiknya, maka untuk biaya pendidikan dan biaya operasional kedua sekolah ini sangat bergantung kepada sumbangan donatur. Walaupun kedua sekolah menerima dana Bantuan Operasional Sekolah (BOS), sumbangan dari para donatur tetap menjadi sumber dana utama bagi sekolah. Akan tetapi, karena pengelolaan keuangan sekolah yang belum akuntabel, maka banyak kendala yang dihadapi sekolah untuk mendapatkan bantuan dana karena terkait masalah kepercayaan para donatur terhadap pengelolaan keuangan. Dari hasil survey awal diketahui permasalahan utama terkait pengelolaan keuangan adalah kerena pembukuan/pencatatan transaksi masih dilakukan secara manual. Komputer/laptop yang dimiliki sekolah digunakan sebatas hanya untuk pengetikan laporan/surat. Selain itu, juga ada keterbatasan kemampuan pengelola administrasi keuangan sekolah, yaitu lulusan Program D3 Jurusan Kesekretariatan. Program IbM yang diusulkan ditujukan untuk membantu kedua sekolah dalam pengelolaan keuangannya dengan merancangkan sebuah aplikasi sistem informasi akuntansi agar pengelolaan keuangan dilaksanakan secara akuntabel. Selain itu, dalam program IbM ini, tim pelaksana juga akan merancangkan prosedur pengelolaan keuangan yang baik, memberikan pelatihan tentang pengelolaan keuangan yang sehat dan pelatihan tentang pengarsipan dokumen keuangan yang baik
\end{abstract}

Kata kunci: Sekolah Dhuafa, sistem informasi akuntansi keuangan sekolah, akuntansi, keuangan

\section{Peran dan Fungsi Akuntansi Dalam Lingkungan Dunia Pendidikan}

Bidang akuntansi berperan dalam berbagai sektor, tidak hanya sektor usaha yang berorientasi laba namun juga sektor-sektor lainnya yang tidak mencari keuntungan semata seperti lembaga pendidikan formal sekolah. Peran dan fungsi akuntansi dalam dunia pendidikan ini adalah: "Menyediakan informasi kuantitatif, terutama yang bersifat keuangan, agar berguna dalam pengambilan keputusan ekonomi dalam entitas pendidikan (Bastian, 2006: 56)". Menurut Bastian (2007: 56) peran dan fungsi akuntansi dalam dunia pendidikan,yaitu:

a. Kepala sekolah: Kepala sekolah menggunakan akuntansi untuk menyusun perencanaan sekolah yang dipimpinnya, mengevaluasi kemajuan yang dicapai dalam usaha mencapai tujuan, dan melakukan tindakan-tindakan koreksi yang diperlukan. 
b. Guru dan karyawan: Guru dan karyawan mewakili kelompok yang tertarik pada informasi mengenai stabilitas dan profitabilitas di institu pendidikan (sekolah).

c. Orang Tua Siswa: Para orang tua siswa yang berkepentingan dengan informasi mengenai kelangsungan hidup institusi pendidikan, terutama perjanjian jangka panjang dan tingkat ketergantungan sekolah.

d. Pemerintah: Pemerintah dan berbagai lembaga yang berda dibawah kekuasaannya berkepentingan dengan aktivitas sekolah. Informasi dasar ini dibutuhkan untuk mengatur aktivitas sekolah, menetapkan kebijakan anggaran, dan mendasari penyusunan anggaran untuk tahun-tahun berikutnya.

Pengelola sekolah dituntut agar dapat memberikan informasi mengenai datadata kuantitatif sekolah terutama yang berkaitan erat dengan jumlah rupiah dana yang dikelola. Dengan kata lain sekolah harus mampu menyajikan laporan keuangan secara transparan, akuntabel, dan dapat dipercaya. Fenomena ini bukan hanya terjadi sekolah-sekolah negeri namun juga pada berbagai sekolah swasta. Apalagi sekolahsekolah gratis yang sumber dana operasionalnya juga berasal dari masarakat (pihak ketiga) sebagaimana halnya yang terjadi di sekolah Dhuafa.

\section{Permasalahan yang dihadapi sekolah}

Sekolah Menengah Kejuruan (SMK) Dhuafa Nusantara Padang dan Madrasah Tsanawiyah Swasta (MTsS) Dhuafa Padang. merupakan sekolah yang didirikan oleh Yayasan Bakti Nusantara Ikatan Sosial Fakir Miskin, Anak Yatim dan Anak Terlantar (Isafat). Pendirian kedua sekolah tersebut dilatarbelakangi oleh banyaknya anak-anak usia sekolah yang tidak dapat melanjutkan pendidikannya karena ketidakmampuan orang tua mereka secara ekonomi. Oleh karena itu sejak tahun 1989 para pendiri Isafat memberikan berbagai kegiatan pelatihan gratis yang diperuntukkan bagi anak-anak fakir miskin, yatim, anak jalanan dan anak terlantar di kota Padang dan sekitarnya berupa pelatihan semir sepatu, pelatihan menjahit, pelatihan las dan pelatihan otomotif. Namun ternyata bekal pelatihan saja tidak cukup bagi mereka untuk menjadikan ketrampilan yang telah dimilikinya sebagai sumber penghasilan, karena pada saat terjun di tengah masyarakat tetap saja dibutuhkan legalitas formal atas keahlian yang telah mereka miliki. Akhirnya dibawah naungan Yayasan Bakti Nusantara Isafat, pada tanggal 18 Agustus 1997 Sekolah Teknik Gratis SMK Dhuafa Nusantara Padang dan pada tahun bulan Juli 2001 mendirikan sebuah sekolah setingkat SLTP yaitu Madrasah Tsanawiyah Swasta (MTsS) Dhuafa Nusantara yang merupakan sekolah terpadu gratis.

\section{SMK Dhuafa Nusantara Padang}

Saat ini SMK Dhuafa Nusantara berkedudukan di Jl. M. Thamrin No. 93 Kelurahan Ranah Parak Rumbio Kecamatan Padang Selatan kota Padang dengan menempati bangunan milik sendiri.

Visi SMK Dhuafa Nusantara adalah : "Mengembangkan pendidikan bagi kaum Dhuafa yang mampu menghasilkan lulusan berkualitas, mandiri, kompetitif, beriman dan bertaqwa". Sedangkan Misi-nya adalah :

1. Memberdayakan pendidikan kaum dhuafa

2. Mewujudkan lulusan sekolah yang berkualitas dan kompettitif dalam skala nasional maupun internasional

3. Mewujudkan sekolah teknik yang mandiri 
4. Mendidik para remaja dan generasi muda yang berwawasan kebangsaan, teknokrat dan religious

5. Mendidik para remaja dan generasi muda yang berwawasan kebangsaan, teknokrat dan religious

6. Mempersiapkan siswa yang mampu berwiraswasta.

Adapun tujuan didirikannya SMK Dhuafa ini adalah:

1. Menyiapkan peserta didik agar menjadi manusia produktif, mampu bekerja mandiri, mengisi lowongan pekerjaan yang ada di DU/DI sebagai tenaga kerja tingkat menengah sesuai dengan kompetensi pada keahlian yang dimilikinya.

2 .Menyiapkan peserta didik agar mampu memilih karir, ulet dan gigih dalam berkompetisi.

3. Menyiapkan peserta didik dengan ilmu pengetahuan, teknologi dan seni agar mampu mengembangkan diri dikemudian hari, baik secara mandiri maupun melalui jenjang pendidikan yang lebih tinggi.

4. Membekali peserta didik dengan kompetensi-kompetensi yang sesuai dengan program keahlian yang dipilih

Saat ini sekolah telah menempati bangunan milik sendiri yang beralamat di Jl.

Sutan Syahrir No. 309 Kelurahan Seberang Padang Kecamatan Padang Selatan. Bangunan sekolah dan pondok pesantren ini sedang dalam proses renovasi karena bangunan tersebut adalah bangunan tua yang sudah tidak memadai lagi dan tidak cukup layak untuk dijadikan ruang belajar siswa. Akan tetapi karena dana yang tersedia belum mencukupi, proses renovasi bangunan hanya bisa dilakukan secara perlahan.

Visi MTsS adalah: Cerdas, kompetitif, berakhlak mulia, berpijak pada iman dan taqwa. Sedangkan misinya adalah:

1. Menanamkan pemahaman mendalam tentang akidah, syari'ah dan akhlak.

2. Ikhlas, disiplin, kreatif, inovatif dan professional dalam bekerja

3. Menjadikan stakeholder's sebagai tambatan dalam pembinaan akhlak siswa

4. Memberdayakan potensi dhuafa untuk bisa kompetitif.

5. Mewujudkan siswa berakhlak mulia, cerdas, terampil, dan bermanfaat bagi agama dan bangsa.

6. Memenuhi 8 komponen standar nasional pendidikan.

Adapun tujuan MTsS adalah:

1. Menciptakan warga madrasah yang berakhlak mulia, mempunyai imam yang kokoh, selalu bertindak dan berbuat sesuai dengan tuntunan Al-Qur'an dan Hadits, disenangi, cerdas, terampil, kompetitif dan selalu memperhatikan kelestarian lingkungan.

2. Mempersiapkan peserta didik agar menjadi manusia produktif.

3. Mempersiapkan peserta didik agar mampu berkarir, ulet, gigih dan kompetitif.

4. Membekali peserta didik dengan ilmu pengetahuan, teknologi agar mampu mengembangkan diri dikemudian hari baik secara mandiri maupun melalui jenjang pendidikan yang lebih tinggi.

5. Membekali peserta didik dengan kompetensi - kompetensi lain sebagai pendukung kompetensi keahliannya.

\section{Permasalahan SMK Dhuafa Nusantara dan MTsS Dhuafa Nusantara}

Keberadaan sekolah gratis sebagaimana yang telah dijalankan oleh SMK Dhuafa 
dan MTsS Dhuafa sangat diharapkan oleh anak-anak fakir miskin, anak yatim, anak terlantar dan anak-anak jalanan karena mereka masih punya kesempatan untuk mendapatkan pendidikan yang dapat dijadikan bekal untuk memperbaiki masa depan agar kemiskinan yang sudah dialami oleh orang tua mereka masing-masing tidak berlanjut kepada mereka. Hanya saja keberlanjutan sekolah gratis tersebut sangat tergantung kepada dana yang terhimpun dari donator (muzakki). Meskipun ada dana bantuan berupa dana BOS dari pemerintah, namun dana itu tidaklah mencukupi untuk membiayai seluruh operasional sekolah. Apalagi untuk pemenuhan sarana dan prasarana yang masih memiliki berbagai kekurangan pada banyak hal.

Untuk meminta atau mencairkan dana, maka sekolah harus mengajukan pengusulan penggunaan dana serta menyerahkan laporan penggunaan dana sebelumnya terlebih dahulu ke Diknas jika dana yang akan dicairkan adalah dana BOS dan ke Yayasan jika dana tersebut berasal dari Yayasan. Tanpa adanya laporan pertanggungjawaban penggunaan dana sebelumnya, maka usulan pengajuan pencairan dana tersebut akan ditolak oleh Diknas maupun oleh Yayasan yang akan berimbas kepada terganggunya operasional serta kegiatan PBM di sekolah.

Selain itu, berdasarkan informasi yang diperoleh Tim Pelaksana dari pihak sekolah, pada awalnya beberapa pihak banyak yang menyangsikan eksistensi sekolah gratis ini, seperti BAZNAS, Pemerintah kota Padang, Pemerintah Sumatera Barat. Itu sebabnya pada awal-awal pendirian sekolah gratis tersebut kurang mendapatkan dukungan berbagai pihak. Jika sekolah memiliki kemampuan dalam menyajikan informasi keuangan sekolah yang akurat, diharapkan tingkat kepercayaan donator, pemerintah dan berbagai pihak lainnya semakin meningkat dan dapat meningkatkan jumlah sumbangan dana dari berbagai pihak tersebut.

Selain hal-hal yang telah diuraikan di atas, permasalahan lainnya yang dihadapi oleh pimpinan di sekolah saat ini adalah sulitnya membenahi sistem informasi di sekolah baik yang terkait administrasi maupun keuangan. Karena selama ini setiap keputusan yang diambil hanya didasarkan pada kebijakan saat itu tanpa adanya sistem operasional prosedur yang jelas baik mengenai administrasi maupun keuangan. Oleh karena itu sekolah sangat membutuhkan sebuah sistem informasi akuntansi yang memadai. Dengan adanya informasi keuangan yang akurat, akuntabel dan dapat dipercaya, hubungan baik antar pihak internal di sekolah juga akan semakin membaik dan meningkatnya saling percaya diantara internal sekolah.

Sebenarnya peluang untuk mendapatkan tambahan dana dari berbagai pihak masih terbuka cukup luas karena keberadaan sekolah gratis tersebut semakin terlihat kebermanfaatannya apalagi beberapa siswa sekolah gratis ini sudah mampu memperlihatkan berbagai prestasi baik ditingkat kota, propinsi maupun di tingkat nasional. Namun permasalahannya, pengelola belum mampu menyajikan informasi keuangan yang dapat diandalkan karena pengelolaan keuangan pada kedua sekolah saat ini masih dilakukan secara manual dan sangat sederhana. Setiap penerimaan dana hanya dicatat kedalam buku harian secara manual. Dengan perkembangan teknologi yang ada saat ini memungkinkan kedua sekolah dapat mengelola sistem keuangannya dengan lebih baik sehingga pengelola dapat menyajikan informasi keuangan yang dikelola dengan lebih professional, dapat dipercaya dan dipertanggungjawabkan. Hal ini diyakini akan memberikan dampak atas tambahan dana dari donator (muzakki).

Selain itu dalam hal administrasi keuangan juga tidak ada keseragaman proses/prosedur. Oleh karenanya perlu dibuat suatu prosedur yang terdokumentasi 
mengenai penerimaan, pengeluaran dan pelaporan keuangan.

Dari uraian di atas, dapat disimpulkan bahwa kedua sekolah memiliki permasalahan yang sama dalam sistem informasi akuntansi. Masalah tersebut adalah

1. Pengelola tidak memiliki pengetahuan tentang akuntansi.

2. Pengelola tidak memiliki kemampuan dalam pengelolaan keuangan, khususnya dalam administrasi dan penyusunan laporan keuangan.

3. Pengelola tidak memiliki kemampuan untuk menyajikan informasi keuangan yang dapat meningkatkan motivasi donatur untuk menambah sumbangannya.

4. Sekolah belum memiliki standar operasi prosedur untuk best practice yang terdokumentasi.

Keberadaan sekolah dhuafa ini sangat diharapkan oleh masyarakat. Sebenarnya peluang untuk mendapatkan tambahan dana masih terbuka cukup luas karena perhatian dari masyarakat cukup tinggi. Namun permasalahannya, pengelola belum mampu menyajikan informasi keuangan yang dapat diandalkan karena sistem keuangan pada kedua sekolah saat ini masih dilakukan secara manual dan sangat sederhana. Dengan perkembangan teknologi yang ada saat ini memungkinkan kedua sekolah dapat mengelola sistem keuangannya dengan lebih baik sehingga pengelola dapat menyajikan informasi keuangan dengan lebih professional, dapat dipercaya dan dipertanggungjawabkan. Hal ini diyakini akan memberikan dampak atas bertambahnya jumlah dana dari masyarakat.

\section{Solusi Permasalahan SMK Dhuafa Nusantara dan MTsS Dhuafa Nusantara}

Dengan semakin bertambahnya jumlah siswa, tentunya akan meningkatkan beban kerja administrasi pengelola khususnya bagian administrasi dan keuangan. Pengelola dituntut untuk dapat melaksanakan tugas administrasi dengan cepat, akurat dan efisien. Aplikasi sistem informasi keuangan sekolah yang dirancang bertujuan untuk memudahkan pelaksanaan tugas-tugas administrasi, keuangan dan akuntansi. Permasalahan yang dihadapi mitra dapat diatasi dengan cara pembuatan sistem informasi keuangan berbasis database. Dengan diterapkannya aplikasi ini, diharapkan dapat mengurangi pekerjaan-pekerjaan manual yang dilaksanakan oleh pengelola terutama pada proses input dan pelaporan. Sistem informasi ini diharapkan dapat mengolah data dan menghasilkan informasi dengan cepat dan akurat.

Untuk merancang sistem informasi akuntansi, dilakukan melalui tahapan-tahapan berikut ini (Mulyadi, 2010):

1.Analisis sistem

Analisis sistem dilakukan untuk mengetahui sistem akuntansi yang sedang dijalankan oleh mitra saat ini, kelemahan/kendala yang dihadapi serta sistem informasi akuntansi yang diinginkan oleh mitra

2.Perancangan Sistem

Berdasarkan analisis sistem yang telah dilakukan, kegiatan selanjutnya adalah merancang sistem yang sesuai dengan kondisi dan keinginan mitra

3.Implementasi Sistem

Sistem informasi akuntansi yang telah dirancang diserahkan ke mitra untuk dilakukan uji coba. 


\section{Analisis Sistem}

Dalam tahap pertama, perlu dilaksanakan observasi dan survey ke sekolah untuk mendapatkan data-data yang dibutuhkan untuk merancang Sistem Informasi Akuntansi mitra. Data yang diperoleh tersebut berupa laporan, dokumen dan catatan keuangan maupun informasi lainnya yang digunakan dalam pelaksanaan operasional keuangan sekolah. Data yang sudah didapatkan diolah dan menjadi dasar dalam menyusun sistem informasi akuntansi yang tepat bagi sekolah ini.

\section{Perancangan Sistem}

Untuk dapat menunjang aplikasi sistem informasi ini dapat berjalan dengan baik, maka diperlukan spesifikasi peralatan (hardware) sebagai berikut:

\begin{tabular}{|l|l|}
\hline \multicolumn{1}{|c|}{ Hardware } & \multicolumn{1}{c|}{ Spesifikasi } \\
\hline Notebook & $\begin{array}{l}\text { Notebook Pavillion } \\
14-\end{array}$ \\
& $\begin{array}{l}\text { AC181TU/AC182TU } \\
\text { (Windows 10) }\end{array}$ \\
\hline Printer & $\begin{array}{l}\text { HP Deskjet 2153 } \\
\text { Multifunction Inkjet } \\
\end{array}$ \\
& Printer \\
\hline $\begin{array}{l}\text { Media } \\
\text { Penyimpanan } \\
\text { Data }\end{array}$ & Terra Expantion 1 \\
\hline
\end{tabular}

\section{Implementasi Sistem}

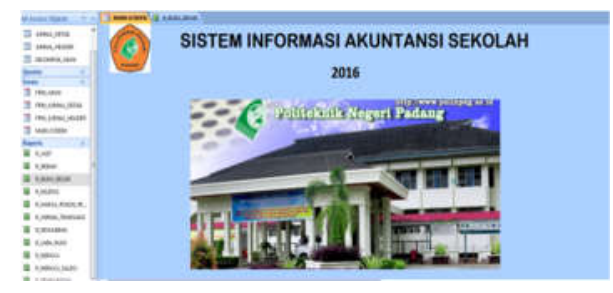

Metode implementasi yang digunakan adalah metode paralel, dimana mitra masih menggunakan prosedur yang selama ini dipakai sambil menggunakan aplikasi yang baru. Pemilihan metode ini untuk menghindari risiko kegagalan sistem baru yang setiap saat bisa terjadi sehingga tidak mengganggu operasional sehari-hari. Selain implementasi software dan hardware, kegiatan ini juga dilengkapi dengan penyusunan buku manual aplikasi sistem informasi akuntansi sekolah.

\section{Evaluasi dan Pendampingan}

Setelah proses implementasi selesai, tim selalu berkomunikasi dan memantau penggunaan aplikasi dan peralatan yang telah diberikan untuk melihat permasalahan yang mungkin terjadinya dan mencarikan solusi yang tepat untuk mengatasi permasalahan tersebut. Apabila mitra sudah tidak mengalami kendala dalam mengoperasikan sistem yang baru dan dirasa sudah bisa untuk mandiri, maka proses implementasi dan evaluasi telah selesai. 


\section{Referensi}

[1] Dahlan, Abdul Aziz. et.al. 1999. Ensiklopedi Hukum Islam. Cetakan II. Jakarta : PT Ichtiar Baru van Hoeve

[2] Ikatan Akuntansi Indonesia. 2010. Standar Akuntansi Keuangan, Jakarta

[3] Bastian, Indra., Suhardjono. 2006, Akuntansi Perbankan, Penerbit Salemba Empat, Jakarta

[4] Madcoms. 2008. Microsoft Access 2007. Yogyakarta: Penerbit Andi dengan MADCOMS.

[5] Mulyadi. 2010. Sistem Akuntansi, Edisi 5. Salemba Empat, Jakarta.

[6] Romney. 2006. Accounting Information Systems. Pearson International

[7] Soemarso SR. 2004. Akuntansi Suatu Pengantar, Salemba Empat. Jakarta. 